\title{
Evaluation of the Effect of Acetylation and Oxidation on Some Functional Properties of Starch Isolated from Dioscorea dumetorum (Wild)
}

\author{
${ }^{1}$ Agbo, I. U. and ${ }^{2}$ Odo, G.E \\ ${ }^{1}$ Department of Pure and Industrial Chemistry, University of Nigeria, Nsukka \\ ${ }^{2}$ Department of Zoology, University of Nigeria, Nsukka
}

Corresponding Author: Agbo, I. U. Department of Pure and Industrial Chemistry, University of Nigeria, Nsukka. Email: iuagbo@yahoo.co.uk

\begin{abstract}
The starch extracted from the wild species of Dioscorea dumetorum were characterized for ash and moisture content, crude fibre, protein and fat. The modified starches were prepared by pre-treatment of the native starch with alkaline and acidic solution at room temperature prior to modification using hypochlorite for oxidation and acetic anhydride for acetylation. Effects of acetylation and oxidation on some functional properties of the starch were evaluated. Variations were observed in the functional properties of the starch as swelling power ranged from 10.3-10.9, solubility index $6.2-7.6 \%$ and apparent amylase content 16.05-21.02\%. Oxidized starch showed higher paste clarity than the acetylated and native starches at $\mathrm{pH}$ 12. The paste clarity of both native and modified starches were found to be $\mathrm{pH}$ dependent. The swelling-power of the native and modified starches put them in the category of highly restricted-swelling starch.
\end{abstract}

Keywords: Dioscorea dumetorum, Starch, Acetylation, Oxidation

Introduction

Starch is one of the most abundant biomacromolecules on earth as renewable and green resources. It is the main components of cereal, grains and tubers. Native starches irrespective of their source are undesirable for many applications (Wang et al., 1993) because native starch in its granular state is insoluble in water. It will swell when mixed with water and can be heated to form a paste. The paste is not stable when stressed by shear, acid or freezing. Under those stresses, syneresis (or water release) will occur as the starch retrogrades or degrades. This makes food preparation very susceptible to microorganisms contamination. The properties of the native starch can be improved by chemical, physical or enzymatic modifications. This increases the application of starches and starch products in variety of ways including food, pharmaceutical, paper, plastic and other manufacturing industries.

Yam, one of the staple foods in Nigeria and other tropical African countries is a monocotyledons tuber bearing plant belonging to the family Dioscoreacea within the genus Dioscorea (Ayensu and Coursey, 1972). Dioscorea dumetorum (bitter yam) which is one of the most economically important species of dioscorea plant usually possesses tubers that are white or lemon in colour. The wild variety which has a climbing spiny vine with stems up to 6-8m high (Onwueme, 1978, Cobley and Steele 1976) is eaten only in times of food scarcity. The tubers of both the edible and wild varieties are processed by boiling. However the wild variety can be left in running water for days to remove poisonous or bitter compounds that are believed to be injurious to health after being sliced and tied in a jute sack (Alozie et al., 2009). The wild forms are very toxic and are sometimes used to poison animals when mixed with bait. Starch obtained from Dioscorea dumetorum has been reported to have small granules (3microns) and to be digestible as cornstarch (Delpeuch and Favier, 1980). Presently, yam is not listed among the most common sources of industrial starch which is primarily provided by corn, potato, wheat, tapioca and rice (Alexander, 1996; Ostertag, 1996; Woolfe, 1992). One of the limiting factors for industrial application of non-official starches such as that from yam is the lack of adequate information on the physicochemical, fundamental and derived properties of the native as well as modified starches (Riley et al., 2006).

This work focuses on the determination of proximate composition of the native starch as well as some functional properties of both native and modified starches extracted from Dioscorea dumetorum with the view to suggesting their possible applications in food, pharmaceutical and other manufacturing industries.

\section{Materials and Methods}

Extraction of starch: The tubers of the cultivated Dioscorea dumetorum (wild) were obtained from local farm in Akama Oghe, Enugu State, Nigeria. The starch was extracted from the tubers by first washing with water, peeled, rewashed and grated to obtain the pulp which was sieved through muslin cloth. The filtrate was allowed to stand for $24 \mathrm{~h}$ and the starch separated by decantation. The separated starch was soaked for $24 \mathrm{~h}$ in a $0.1 \mathrm{~N}$ sodium metabisulphite solution and thereafter washed thoroughly to free it of this reagent. The slurry was then soaked in $0.1 \mathrm{~N}$ sodium hydroxide until neutral. It was then soaked in $0.1 \mathrm{~N}$ sulphuric acid for $12 \mathrm{~h}$ after which it was washed thoroughly. The resulting starch slurry was decanted after $24 \mathrm{~h}$. The wet starch cake was dried in the oven at $40^{\circ} \mathrm{C}$, ground into fine powder, packaged into transparent 
polyethylene bag and labeled prior to analysis (Attama et al., 2003).

Preparation of oxidized starch: The oxidized starch was prepared by the method of Ogungbenle (2007) with modifications. Starch $(30 \mathrm{~g})$ was dispersed in $150 \mathrm{ml}$ distilled water. The $\mathrm{pH}$ of the slurry was adjusted to 9.0 using $3 \% \mathrm{NaOH}$. $3 \mathrm{ml}$ of $\mathrm{NaOCl}$ was added slowly with constant stirring using magnetic stirrer. The reaction was carried out for $30 \mathrm{~min}$. The process was repeated using fresh sample of starch, but for $4 \mathrm{~h}$ oxidation duration. The $\mathrm{pH}$ of the mixture was then adjusted to 7.0 using $0.5 \mathrm{M} \mathrm{HCl}$ and the slurry was later filtered through filter paper. The residue was then washed thoroughly with distilled water and dried in the oven at $400 \mathrm{C}$.

Preparation of acetylated starch: The method of Ogungbenle (2007) was also used with slight modifications. Starch $(50 \mathrm{~g})$ was dispersed in $250 \mathrm{ml}$ of distilled water and then constantly stirred for 30 min with magnetic stirrer. The slurry was adjusted to $\mathrm{pH} 8.0$ with $\mathrm{NaOH}, 5.5 \mathrm{ml}$ of acetic anhydride was then added to the slurry. After the addition of the acetic anhydride the reaction was allowed to proceed for another five minutes. The $\mathrm{pH}$ of the slurry was adjusted to 4.5 with $0.5 \mathrm{M} \mathrm{HCl}$ and filtered through filter paper. The residue obtained was washed several times with distilled water and finally air dried at room temperature.

Proximate analysis: Proximate composition of starch was determined according to the method of AOAC (1980) for moisture, total ash, total crude fibre, crude fat and total crude protein, respectively. Carbohydrate was obtained by difference. All results were the average of triplicate analyses.

Determination of swelling power: This was determined using the method described by Leach et al. (1959) with modification for small samples. The sample $(0.5 \mathrm{~g})$ was weighed into a weighed test tube into which $10 \mathrm{ml}$ of distilled water was added and heated in water bath at temperature of $900 \mathrm{C}$ for $20 \mathrm{~min}$. This was continually stirred within the heating period to keep the starch granules suspended. At the end, the test tube was centrifuged at $1000 \mathrm{xg}$ for $30 \mathrm{~min}$ in order to facilitate the removal of the supernatant which was carefully decanted and the weight of the starch paste taken. Swelling power was calculated thus: Swelling power = weight of starch paste / weight of dry starch sample.

Determination of solubility index: Solubility index was evaluated by weighing $1 \mathrm{~g}$ of starch into $20 \mathrm{ml}$ of distilled water in a test tube. This was subjected to heating in a water bath at a temperature of $900 \mathrm{C}$ for $20 \mathrm{~min}$. At the end of heating, it was subjected to centrifugation at $1200 \times \mathrm{xg}$ for $30 \mathrm{~min}$ and the supernatant was decanted and dried to constant weight and the solubility index was expressed as the percent by weight of dissolved starch from a heated solution (Kainuma et al., 1967).
Determination of paste clarity: The method reported by Nand et al., (2008) was used for paste clarity determination. Starch samples were suspended in distilled water to yield $1 \%(\mathrm{w} / \mathrm{v})$ slurries. The $\mathrm{pH}$ of the slurries were adjusted to 2, 4, 6, 8, 10 and 12 by the addition of either $0.1 \mathrm{M} \mathrm{HCl}$ or $0.1 \mathrm{M} \mathrm{NaOH}$ as the case may be. The tubes were then heated in a boiling water bath with occasional stirring for $30 \mathrm{~min}$. After cooling, the percentage transmittance (\%T) at $650 \mathrm{~nm}$ was determined against water as a blank using spectronic 20D spectrophotometer.

Determination of the size starch granules: Dry starch samples were dispersed into distilled water and the samples viewed under a photomicroscope at a magnification of $400 x$. The size of the starch samples granules was determined.

Determination of amylose: Mc-Gready and Hassid colourimetric (1948) method was used to determine amylose content in starch samples. A $0.1 \mathrm{~g}$ dried defatted sample was dispersed in $2 \mathrm{ml}$ ethanol, then $10 \mathrm{ml}$ distilled water and $2 \mathrm{ml}$ of $10 \% \mathrm{NaOH}$ were added. The mixture was heated on a hot plate until a clear solution was obtained. The clear solution was made up to mark in $100 \mathrm{ml}$ volumetric flask. $5 \mathrm{ml}$ of the solution was pipetted into $100 \mathrm{ml}$ flask, followed by the addition of 3 drops of $6 \mathrm{~N} \mathrm{HCl}$ and $5 \mathrm{ml}$ iodine solution $(0.2 \%$ iodine in $2 \%$ potassium iodide) were added and the volume made up to mark with distilled water. It was allowed to stand for 20min for maximum colour development and absorbance recorded at $640 \mathrm{~nm}$. The concentration of the amylose was determined from a standard curve measured with pure amylose.

\section{Results and Discussion}

IR and photomicroscopic analysis: Starch is a digestible polysaccharide. Starch may be linear (amylose) and branched (amylopectin). It is a polysaccharide unit. The hydroxyl groups $(\mathrm{OH})$ which are the major functional group appeared in the region $3650 \mathrm{~cm}-1-3200 \mathrm{~cm}-1$. The introduction of carboxyl group by oxidation now shifted the spectral peaks to appear around $1842 \mathrm{~cm}-1$ $1670 \mathrm{~cm}-1$. When the starch was acetylated, peaks around the region $1750 \mathrm{~cm}-1-1730 \mathrm{~cm}-1$ was observed. The results obtained from the infrared spectroscopic analysis confirmed the introduction the introduction of carboxyl and acetyl groups respectively into the modified starches.

Proximate compositions of the native starch were moisture $6.5 \%(\mathrm{w} / \mathrm{w})$, crude fat $1 \%$ $(\mathrm{w} / \mathrm{w})$, crude protein $1.3 \%(\mathrm{w} / \mathrm{w})$, and ash content $0.48 \%(\mathrm{w} / \mathrm{w})$. Carbohydrate content was found to be $90.18 \%(w / w)$. Hypochlorite- oxidized starches produced aqueous dispersion of greater clarity, less gelling tendency than those of the native starch. The oxidized starches were seen to be progressively whiter and finer to touch with increasing duration of oxidation. The increased starch granule whiteness with increase in oxidation duration was due to the bleaching effect of the hypochlorite treatment, the solubilization and washing out of protein and associated pigments from the starch granules (Attama et al., 2003) 
The starch samples viewed under a photomicroscope at a magnification of $400 \mathrm{x}$ showed a tiny or spherical granules. The tiny granules decreased with oxidation as shown in figure 1. Starch obtained from Dioscorea dumetorum has been reported to have small granules (3microns) and to be digestible as cornstarch (Delpeuch et al., 1980).

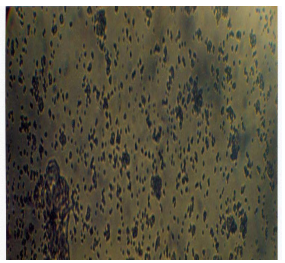

(a) D. dumetorum, native starch

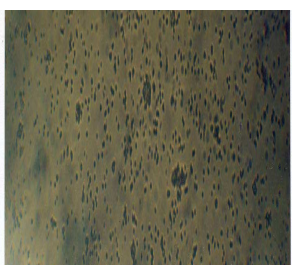

(c) D. dumetorum, acetvlated starch

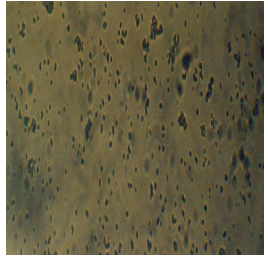

(b) D. dumetorum, oxidized (30 min)

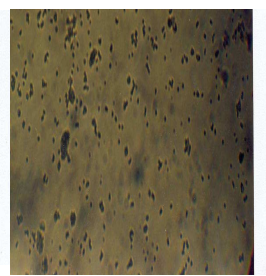

(d) D. dumetorum, oxidized (4 hours)

Fig. 1: Photomicrographs of (a) native (b) oxidized for $30 \mathrm{~min}$.(c) oxidized for $4 \mathrm{~h}$ (d) acetylated starches (X 400)

Table 1: Paste clarity of native and modified starches at different $\mathrm{pH}$ values

\begin{tabular}{lllll}
\hline $\mathbf{p H}$ & \multicolumn{5}{l}{ Percent } & \multicolumn{4}{l}{ Transmittance } \\
\hline $\mathbf{2}$ & 5.68 & 4.32 & 14.03 & 7.01 \\
$\mathbf{4}$ & 4.33 & 3.27 & 8.93 & 6.56 \\
$\mathbf{6}$ & 6.89 & 6.93 & 13.84 & 12.71 \\
$\mathbf{8}$ & 5.32 & 6.59 & 21.13 & 15.28 \\
$\mathbf{1 0}$ & 5.64 & 8.13 & 27.10 & 41.50 \\
$\mathbf{1 2}$ & 70.47 & 77.46 & 83.95 & 72.95 \\
\hline
\end{tabular}

Paste clarity: The results of paste clarity are shown in Table 1. The oxidized starch (4h) had higher paste clarity (83.95\%) when compared to acetylated starch $(72.95 \%)$ at $\mathrm{pH} 12$. The native starch had the lowest paste clarity $(70.47 \%)$ at $\mathrm{pH} 12$. The paste clarity decreased slightly from $\mathrm{pH} 2-\mathrm{pH} 4$. However the light transmission increased gradually from $\mathrm{pH} 4$ $-\mathrm{pH} 10$ and significant increase was observed at $\mathrm{pH}$ 12. This can be explained in terms of granular swelling, resulting from repulsion between adjacent negative charges centered on the hydroxyl groups of complexed lysophospholipid molecules (Nand et al. 2008). The high clarity observed for oxidized starch pastes signified that the starch granules of these samples are fragile during pasting and remnants of granules are absent from the paste.

Apparent amylose content: The apparent amylose content varied among the starches studied. The oxidized starch had highest amylose content $(21.02 \%)$ while native had the lowest $(16.05(\%)$ as shown in Table 3. The higher the amylose content, the lower is the swelling power and the slower is the gel strength. This may be because oxidation cleaves the links within the starch polymer as well as carbon to carbon bonds in the starch molecule to produce carboxyl and carbonyl groups. The starch chains are now much shorter and this limits the starch's ability to absorb water. It has been reported that starches with high amylose/low amylopectin contents tend to be of the type B structure while those with low amylose/high amylopectin content are of either the type-A or typeC form (Padmanabhan and Lonsane, 1992).

Table 2: Proximate composition of native starch

\begin{tabular}{lc}
\hline Tests & Percent content \\
\hline Moisture & 6.5 \\
Crude protein & 1.3 \\
Ash & 1.0 \\
Fat & 1.0 \\
Crude fibre & 0.0 \\
\hline Results are the means of triplicate determinations
\end{tabular}

Results are the means of triplicate determinations

The type $A$ and type $C$ starches are more digestible than type B starches. Previous report (Riley et al, 2006) has shown that the amylose content plays a key role in the digestion of starches, as starches with low amylose contents were found to be more digestible than starches with high amylose content. This implies that the starches may be digested and absorbed at a slow rate, thereby releasing their product of digestion slowly as they pass through the digestive tract. Starches that are digested and absorbed at a slower rate would result in lower blood glucose responses, while those which are digested and absorbed at a faster rate would produce large increase in the blood glucose, which may necessitate greater insulin and other endocrine responses when ingested. The low digestibility of the starches could be of significance to diabetics and other health conscious individuals.

Swelling power and water solubility index: The swelling power and water solubility index of the modified and native starch at $90^{\circ} \mathrm{C}$ are shown in Table 3. Both the unmodified and modified (acetylated and oxidized) starches were insoluble in water at room temperature and as a result, solubility was determined at $90 \mathrm{oC}$. The solubility index values of the starch samples ranged from $6.2 \%-7.6 \%$ $(w / w)$. Starch with highest oxidation duration had the highest solubility index value $(7.6 \% \mathrm{w} / \mathrm{w})$ while native had the lowest solubility index of $6.2 \%(\mathrm{w} / \mathrm{w})$.

The swelling power which is the measure of the ability of starch to imbibe water and swell ranged from 10.3 to 10.9 . The results of the swelling power study indicate that the starches both modified and native are of the highly restricted type. According to Schoch and Maywald (1968), starches have been classified as high swelling, moderate swelling, restricted swelling, or highly restricted swelling. High-swelling starches have swelling power of approximately 30 or higher at $95^{\circ} \mathrm{C}$. Their granules swell enormously and the internal bonds become fragile toward shear when the starch is cooked in water. Restricted-swelling starches have swelling power in the range of 16 to 20 at $95^{\circ} \mathrm{C}$. The cross-linkages in their granules reduce swelling and stabilize them against shearing cooking in water (Galvez and Resurreccion, 1993). The low swelling 
power displayed by modified starches may be as a result of the extensive and strongly bonded micellular structure as such starches are relatively resistant to swelling (Lorenz, 1990). The observation made with native starch with low amylose content and high swelling power complied with earlier report by Riley et al., 2006. The swelling power of starches is of great significance in tablet and capsule formulations, as it is believed that disintegrants work through a swelling and wicking action. As a result, starches with higher swelling power would be expected to release the active pharmaceutical ingredient from its compacts at a faster rate. This therefore implies that tablet and capsule formulated with the native starch as disintegrants would release the drug at a faster rate while those formulated with the modified starches would be slow.

Table 3: Some functional properties of the native and modified starches

\begin{tabular}{lllll}
\hline $\begin{array}{l}\text { Functional } \\
\text { Properties }\end{array}$ & $\begin{array}{l}\text { Native } \\
\text { starch }\end{array}$ & $\begin{array}{l}\text { Acetylated } \\
\text { starch }\end{array}$ & $\begin{array}{l}\text { oxidized } \\
\text { starch } \\
\text { (30min) }\end{array}$ & $\begin{array}{l}\text { Oxidized } \\
\text { starch } \\
\text { (4hr) }\end{array}$ \\
\hline $\begin{array}{l}\text { Apparent } \\
\text { amylose } \\
\text { content (\%) }\end{array}$ & 16.05 & 18.67 & 19.53 & 21.02 \\
$\begin{array}{l}\text { Swelling } \\
\text { power }\end{array}$ & 10.92 & 10.88 & 10.68 & 10.32 \\
$\begin{array}{l}\text { Solubility } \\
\text { index (\%) }\end{array}$ & 6.20 & 6.60 & 6.40 & 7.60 \\
\hline $\begin{array}{l}\text { The percent soluble and swelling powers were calculated } \\
\text { on dry basis. All values are means of triplicate } \\
\text { determination. }\end{array}$ & & & &
\end{tabular}

Conclusion: The functional characteristics of native and modified Dioscorea dumetorum had some variations. The swelling power of the native and modified starch samples studied fall on the group of highly restricted - swelling starches according to Schoch and Maywald (1968). This characteristic is desirable for starch extracts to be used for the manufacturing of value added products such as noodles and composite blends with cereals. Starch from Dioscorea dumetorum has small or tiny granules, thus can be easy digestible. It can therefore be widely used in baby food, and the diet of people allergic to cereals and children sensitive to milk. From the results of the study, it can be concluded that the applicability of the starch sample investigated were enhanced by the chemical modifications and thus enable their properties compare favorably with cereal starches. This indicates that Dioscorea dumetorum starch can be used in food processing industry, pharmaceutical manufacture and other fields such as in paper, plastic and textile industries. Research is in progress to utilize both the native and modified starches this for the preparation of biodegradable material.

\section{References}

Alexander, R.J. (1996). Starch in plastics. Cereal Foods World 41:426 -427.

Alozie, Y., Akpanabiatu, M.I.; Eyong, E.U.; Umoh, I.B.; Alozie G. (2009). Amino acid composition of Dioscorea dumetorum varieties. Journal of Nutrition 8(2): 103105.

AOAC (1980). Official Methods of Analysis. 13th edn, Association of Official Analytical Chemists.

Attama, A.A., Nnamani, P.O., Mbonu, I.K. and Adikwu, M.U. (2003). The effect of hypochlorite oxidation on the physicochemical properties of Gladiolus starch. J. Pharm. and Allied Sci. 1(1) 2835.

Ayensu, E.S., Coursey, D.G., (1972). Guinea yams. The botany elhnobotany, use and possible future of yams in West Africa. Econ. Bot.26:301 -318.

Cobley, L S and Steele, W M (1976), An Introduction to Botany Crop, 2nd ed. London, P. 371.

Delpheuch F. and Favier J.C.(1980). Caracteristiques des amino de plantesalimentaires tropicals: Action de l'amylase, gonflement et solubilite. Anal. Technol. Agri.27: 809-826.

Galvezs, E.C.F. and Resurreccion, A.V.A. (1993). The effects of decortication and method of extraction on the physical and chemical properties of starch from mung bean (Vigna radiate (L) wilezec). Journal of food processing and preservation, 17: 93-107.

Kainuma, K., Odat, T. and Cuzuki, S. (1967). Study of Starch phosphates monoesters. J. Technol. Soc. Starch, 14:24-28.

Leach, H.W., McCowan, L.D. and Schoch, T.J. (1959). Swelling and solubility patterns of various starches. Cereal Chem.36: 534 544.

Lorenz, K. (1990). Quinoa (Chenopodium quinoa) Starch: Physico-chemical properties and functional characteristics. Starch/Starke 42: 81-86.

McCready, R.M. and Hassid, W.F. (1943). The separation and quantitative estimation of amylose and amylopectin in potato starch. Journal of the American Chemical Society, 65: 11-54.

Nand, A.V., Charan, R.P., Rohindra, D. and Khurma, R.J. (2008). Isolation and properties of starch from some local cultivars of Cassava and Taro in Fiji. South Pacific Journal of Natural Science, Vol. 26. 45-48

Ogungbenle, H.N. (2007). Effect of chemical modification on starch of some legume flours. Pakistan J. Nutri. 6(2): 167-171.

Onwueme, I.C. (1978). The tropical tuber crops: Yams cassava sweet potato and cocoyams. John Wiley and Sons ,Chichester, London p.234

Ostertag C. (1996). World production and marketing of starch. In: Cassava flour and starch: progress in research and development. Cali. Columbia, pp. 105-120.

Padmanabhan, S. and Lonsane B.K. (1992). Comparative physiochemical and functional properties of cassava starches obtained by conventional and enzyme- 
integrated conventional techniques Starch/Starke 44:328-332.

Riley, L.K., Wheatley, A.O. and Asemota, H.N. (2006). Isolation and characterization of starches from eight Dioscorea alata cultivars grown in Jamaica, Afri. J. Biotechnol. 5(17), pp. $1528-1536$.

Robin, J.P. (1976). Comportement du grain amidon a l'hydrolyse acide menagee. Etude physicochimique et enzymatique de la fraction insoluble. Contribution a la connaissance de la structure de l'amylopectine. These de Doctoratesscunces physique, CNRS AO 12534. Paris, France.
Scholch, T.J. and Maywald, E.C. (1968). Preparation and properties of various legume starches. Cereal chemistry, 45: 564-573.

Stuart, A.S.C, M. Cladualdoc, A.S Paul and R.C Hosenney, (1989). Starch paste clarity. Cereal Chemistry 66: 173-182).

Wang, Y J., White, P., Pollak, J. L., (1993). Characterization of starch structures of 17 maize endosperm mutant genotypes with Oh 43 inbred line background. Cereal Chem.10: $171-179$.

Woolfe, J.A. (1992). Sweet potato, an untapped food resource. Cambridge University press. UK, p. 643. 